\title{
Situating gangs within Scotland's illegal drugs market(s)
}

\author{
Robert McLean $^{1}$ - James A. Densley ${ }^{2}$. \\ Ross Deuchar ${ }^{1}$
}

\begin{abstract}
The Scottish government's (2008) publication 'The road to recovery: A new approach to tackling Scotland's drug problem' elaborates and outlines the Scottish National Party's (SNP) desire to make Scotland 'drug free' by 2019. To achieve this objective, the Scottish Government's (2015) 'Serious Organised Crime Strategy' (SSOCS) entails dismantling networks of drug supply. Yet missing from this strategic planning is a) recognition of how, if at all, different types of gangs are involved in drug supply, and b) how drug supply processes actually work. Therefore, this article seeks to extend McLean's (J Deviant Behav, 2017) Scottish gang model, which specifies a typology of gangs in Scotland, in an effort to locate precise levels of gang involvement in the drugs market. This is achieved by drawing upon Pearson and Hobbs' (2001) hierarchical model of the UK's illegal drug(s) market. In-depth interviews with 35 offenders involved in criminal networks and five practitioners, indicate that recreational Youth Street Gangs are really only involved in 'social supply'. Youth Criminal Gangs are primarily involved in commercially motivated dealing at the low- to mid-levels, including bulk-buying between the retail-to-wholesale markets. And enterprising Serious Organised Crime Gangs operate from the middle-to-apex market level. Conclusions which situate this gang typology within the illegal drug market(s) are used to put forward recommendations aimed at dismantling of drug supply networks.
\end{abstract}

Keywords Drugs · Gangs · Organised crime $\cdot$ Scotland

Robert McLean

robert.mclean@uws.ac.uk

1 Interdisciplinary Research Unit on Crime, Policing and Social Justice, School of Education, University West of Scotland, Ayr, UK

2 School of Law Enforcement and Criminal Justice, Metropolitan State University, Saint Paul, MN, USA 


\section{Introduction}

Scotland has a particularly acute drugs problem both in relation to drug usage and supply (Scottish Government 2009a, 2015). In Scotland, 'levels of problematic drug use. ... and drugs crime are among the highest in the world' (McCarron 2014: 17). There are an estimated 200,000 problematic drug users and 600,000 recreational drug users in a country of 5.3 million people, with anywhere between 40,000 and 60,000 children affected by parental drug misuse (Casey et al. 2009). Drug harms are thought to cost the Scottish economy around $£ 3.5$ billion annually (Scottish Government 2009a) Against this backdrop, the Scottish National Party (SNP) pledged to make Scotland 'drug free' by 2019 (Scottish Government 2008). To achieve this objective, the Scottish Government's (2015) Serious Organised Crime Strategy (SSOCS) is focused on dismantling drug supply.

Scotland's 'Serious Organised Crime Strategy' incorporates the tactics of 'diverting', 'deterring', 'detecting', and 'disrupting' drug supply and, in so doing, dismantling criminal networks (Scottish Government 2015). Drug supply, therefore, is delineated under the umbrella term 'organised crime' (OC), which, by definition, is perpetrated by 'Serious Organised Crime Groups' (SOCGs). Such groups are defined as 'a) involving more than one person, b) organised, meaning that it involves control, planning and use of specialist resources, c) causes, or has the potential to cause, significant harm, and d) involves benefit to the individuals concerned, particularly financial gain' (Scottish Government 2015: 6). While such broad definitions of OC are expected in policy circles (see Varese 2010; von Lampe 2016), by incorporating drug supply into the 'black box' of OC (see Decker et al. 2008), law enforcement neglect potentially important differences within and between crime types and downplay the practical significance of distinct supply typologies (see Coomber and Moyle 2014).

If the Government wants to bring the idea of a drug free Scotland to fruition, a more nuanced understanding of the drug supply process is required. Focus on 'Serious Organised Crime Groups', broadly defined, is insufficient. The current study, therefore, elaborates upon this concept to demonstrate how drug supply really works within the Scottish context. A full analysis detailing every aspect of drug supply is beyond the scope of one paper. This study addresses the topic from the perspective of group, or gang, processes and superimposes gang typology over the different levels of Scotland's illict drugs market(s). This is important because crime and other social harms in Scotland typically are linked to 'gang' problems, or discussed within what has essentially become a 'gang-talking' discourse (see Hallsworth and Young 2008). Analysing supply chain processes as a whole from a group, or gang, perspective facilitates identification of the criminals who seek to link drug importers to street level dealers and consumers, which can inform drug enforcement policy and practice.

The current study first and foremost reviews the existing literature on Scotland's drug problem, gang typologies, including Mclean's (2017) evolving gang model, and the role of gangs in Scotland's drug market. Next, we outline the data sources and method. This is followed by the findings, which detail differences between gang type and drug supply type. A discussion follows situating the findings within the context of Pearson and Hobbs' (2001) illegal drugs market model. Finally, the conclusion illustrates how this research provides a foundation upon which future studies can build, with implications for policy and practice. 


\section{Literature review}

\section{Drugs in Scotland}

In 2008, the SNP announced a 'new approach to tackling Scotland's drug problem', a strict prohibitionist model reminiscent of the American experience. ${ }^{1}$ This 'new approach' focused primarily on tough enforcement to address drugs supply and the 'criminals' associated with drug use and possession (Scottish Government 2008, 2009b). The supposed link between drugs and crime has been a defining feature of discourse around the UK drug problem in recent years. In policy circles, it is believed that individuals involved in drug use and drug supply are likely to be profoundly involved in acquisitive crimes (McPhee 2013). Thus, concepts such as 'drug-related' or 'drug-driven' crime have become central to UK drug policy (Stimson 2000). McPhee (2013) attributes much of the contemporary discourse around drugs in Scotland to that of 'drug-talkers' discussing the relationship between drugs and crime as though it were given, despite evidence to the contrary (Stevens 2008). There are similarities here with 'gang talk', wherein all crime is attributed to 'gangs', loosely defined, whether or not 'gangs' are involved at all (Hallsworth and Young 2008). In turn, any effort to address crime must first address drugs and/or gangs.

The criminalisation of social policy in Scotland, and ultimately working-class populations in the process (Deuchar and Bhopal 2017), has gradually brought the 'drug talking' and 'gang talking' discourses together. Gangs, for example, have come to be seen as the primary outlet for drug distribution. The overlap of gangs and drugs is well-documented in the literature (e.g., Bjerregaard 2010; Decker 2000). Gang members are significantly more likely than their non-gang counterparts to be involved in drug sales, for example, although the proportion of gangs that are centred around drug distribution and that effectively control the operations thereof is relatively small (Fleisher 2015). The rhetorical nexus between gangs and drugs, however, has perpetuated the idea that gangs control the distribution of drugs, from the street-level up. Police Scotland, for example, explain drug crime in terms that 'gangs/groups sell drugs' (Scottish Government 2015). Use of umbrella terms like 'gangs' and 'drug dealing' has the potential to prove highly misleading if they are not unpacked properly; particularly given that the use of such language brings along with it subjective labels, prefixes, and presumptions (see McLean 2017).

The conflation of 'gangs' and 'drugs' is steadily gathering momentum in the Scottish context, but understanding of illicit market structure and behaviour is considerably underdeveloped and under-researched. In recent years, there has been an academic pursuit anent illegal drug market definitions and processes, yet efforts to capture market complexities have fallen short owing to the fact that market activities are illicit, even to those operating within (Coomber 2004). Few models of the illegal drugs market currently exist, and while they are quite simplistic, they nonetheless lay a foundation from which the present research can build. For example, May and Hough (2004) outline two market forms in Scotland as being dominant: a top down pyramid model and a highly-fragmented model. Adopting a top down perspective, Preble and Casey (1969) outline a three-tier model, with drugs being imported into the country before being passed to wholesalers and then retail-level

\footnotetext{
${ }^{1}$ While this is evident in a number of ways, one of the most obvious is the creation of a USA style Drug Enforcement Administration (DEA), known initially as the Scottish Drug Enforcement Agency (SDEA), and later renamed the Scottish Crime and Drugs Enforcement Agency (SCDEA) in an effort to firmly establish links between crime and drugs.
} 
distributors. Coope and Bland (2004) outline a similar model as being applicable to the contemporary Scottish context, taking into account globalisation processes that influence the size and scale of the illegal drugs market. And Pearson and Hobbs' (2001) four-tier model, relevant to the entire UK context, extends previous models by describing how 'middle-men' connect wholesalers to retail-level distributors.

Recent studies conducted in London, England, by Densley (2012, 2013) and Pitts (2008) indicate a significant increase in gang involvement within illegal drug markets, to the extent that gang involvement may span several market levels. For example, there is evidence that gangs in London cross police borders to exploit provincial drug markets; a model known as 'county lines' dealing (Coomber and Moyle 2017; Storrod and Densley 2017). McPhee et al. (2009) note that while a hierarchical model may be the most applicable to the Scottish drugs market, those lines of business between levels and specific roles within are anything but clear and require further analysis. Thus, with a growing tendency to attribute drug supply to gang activity, an understanding of the Scottish gang, in its various forms, is also required in order to avoid broad generalisations and umbrella terminology: particularly given that in Scotland, 'gang' is anything but a unified term (Miller 2015), and how gangs/groups operate varies considerably by geography.

\section{Gang types}

Since the first study of gangs (Thrasher 1927), gang researchers have used typologies to distinguish one gang from another and group gangs together according to behavioural or structural criteria (Klein and Maxson 2006). Most typologies are based on behavioural, rather than structural aspects of gangs, namely involvement in deviant or criminal behaviours. Cohen and Short Jr (1958) and Cloward and Ohlin (1960), for example, famously delineated different delinquent subcultures, while Yablonsky (1962), Fagan (1989), and Taylor (1990) identified specific gang types according to differential involvement in drugs, crime, and violence. Structural typologies, by contrast, focus on aspects of the horizontal and vertical 'structure' of gangs. Perhaps the most influential example is Maxson and Klein's (1995) five-group classification of gangs: (a) traditional gangs, (b) neo-traditional gangs, (c) compressed gangs, (d) collective gangs, and (e) speciality gangs. Only on rare occasions have behavioural and structural typologies been combined (e.g., Bouchard and Spindler 2010), in part because some see gangs' well documented offending 'versatility' as incongruous with any specification of behavioural 'patterns' (Klein and Maxson 2006).

The number and variety of gang typologies, and the fact that most of them are not well articulated with each other (Densley 2012), speaks to the different data sources and methods researchers rely on to arrive at their conclusions. The general absence of group level data in gang research (see Klein 1995; Short 1998), for example, has curtailed examination of the relationship between gang form (structure) and function (behaviour). Self-report studies rely heavily on predesignated indicators of gangs and individual perceptions of group organisation, rather than direct measures (Decker et al. 2008). Ethnographic studies have inherent selection biases, such as an orientation toward big gangs in big cities with 'chronic' gang problems (Spergel 1995), and have not been generalizable (Hughes 2005). And law enforcement and criminal justice data speak to the collateral consequences of the very construction of gangs in terms of behaviour or structure (Klein 1995). As a result, gang typologies can be thought of as 'ideal types' in the Weberian sense - they do not necessarily reflect reality because objectively nothing can, but they can help to clarify one's observations. 
For example, typologies have helped articulate how gang organisation exists on a continuum (Densley 2014), with 'instrumental-rational' (organised) groups at one extreme, and 'informal-diffuse' (disorganised) groups on the other (Decker et al. 1998, 2008). Instrumental-rational depictions of gang organisation include group ends, age-graded levels of membership, leadership roles, coordinated drug sales, and rules and codes of conduct (Decker and Pyrooz 2013). The informal-diffuse perspective, by contrast, finds gangs with 'functional and situational' leadership and 'freelance' members who distribute drugs for individual, not collective, ends (Decker and Pyrooz 2013). Research shows how a gang's level of organisation affects levels of delinquency and victimization. General consensus is both offending, particularly violent and drug crime, and victimization increase with levels of gang organisation (Decker et al. 2008; Sheley et al. 1995; Bouchard and Spindler 2010), but not one organisational characteristic consistently predicts increases in delinquency or victimization (Pyrooz et al. 2011).

While there is greater empirical support for the existence of disorganised gangs (Decker et al. 2008), there is certainly no 'single unified gang problem' (Curry 2000: 1254), and to some extent, more organised gangs may better constitute 'organised crime' (see Densley 2012), a concept which itself has been contested and subject to many typologies (see von Lampe 2016). Hallsworth and Young's (2006) heuristic typology of urban street 'collectives', influential in the UK context, for example, places gangs below organised crime groups in a pyramidal hierarchy of offending 'risk'.

\section{Gangs in Scotland}

Gangs are by no means a new phenomenon in Scotland. The country's largest city, Glasgow, has an especially long history of gangs (see Davies 2007, 2008, 2013; Fraser 2015; Patrick 1973; Miller 2015). Early in the twentieth Century, for example, Glasgow was coined the 'Scottish Chicago' owing to its sectarian gang violence (Davies 2007). Then, early in the twenty-first Century, Glasgow was branded 'Europe's Knife Capital,' thanks, in part, to escalating gang violence (McCallum 2011). Like the city itself, Glasgow's gangs have evolved over time and in concert with wider cultural, socioeconomic, and political change. Whereas the 'razor' gangs of the 1920s were a product of large-scale Irish immigration, sectarian tension, and economic recession (Davies 2013), ${ }^{2}$ the post-industrial gangs, or 'Young Teams' (Miller 2015), of today are predominantly the consequence of constrained masculinities and territoriality (Fraser 2015). Likewise, in what is now a globalised society, gangs in Scotland, as in the UK more generally, are gradually being found to be involved in drug supply processes as entry into global drugs markets continues to becomes more readily accessible (see Densley 2012, 2013; Hales and Hobbs 2010; McLean 2017; Pitts 2008).

History notwithstanding, there remains little official agreement as to what exactly constitutes 'gang' in the Scottish context (Deuchar 2009, 2013). The term is used to describe both diffuse delinquent youth groups involved in territorial violence and adult criminal groups carrying out acquisitive crimes, and everything in-between (see Fraser 2015). The lack of a unified gang definition in Scotland is due in part to the ever-changing

\footnotetext{
${ }^{2}$ While the barbers' razor, used by the razor gangs of the $1920 \mathrm{~s} / 30 \mathrm{~s}$, is no longer the weapon of choice amongst Glasgow gangs, the tradition of carrying and subsequently using a knife or other sharp instrument is still a practice which exists today.
} 
manifestation of 'gangs' (Densley 2014). Consequently, workable, rather than unanimous, definitions have been adopted to meet the needs of agencies or institutions that interact with or describe certain groups or segments of the population involved in 'problematic' behaviour (Bartie 2010). The result has been a blurring and consolidation of gang definitions, typologies, structures and behaviours all under the one umbrella term, which has undoubtedly created confusion and fear around all things labelled 'gang'.

To help clarify the term 'gang' in the Scottish context, ${ }^{3}$ McLean (2017) recently presented an evolving gang model linking early offenders in Young Street Gangs (YSGs) to organised criminals in SOCGs. ${ }^{4}$ Like Densley (2012), McLean argued persistent high-end offenders involved in the hard-drug economy seldom arise from nowhere, but rather harness and refine criminality over sustained durations, often in groups or with co-offenders (see Decker 2000). McLean therefore argues gang organisation exists on a continuum, whereby organised criminal adult groups situate one end, and disorganised delinquent youth gangs the other.

While McLean seeks to negotiate the structure/behaviour nexus when situating gang/ group positions on the continuum, ultimately, in accordance with existing Scottish gang literature (e.g., Deuchar 2009; 2013; Fraser 2015; Patrick 1973), McLean defined gangs predominantly through behavioural attributes, but structural properties may, or may not, emerge through these behaviours. For example, while all diffuse and disorganised gangs retain evolving capabilities, often it is only those which seek to organise as a means for 'business' that evolve. Typically, organisation occurs when individual group members seek to respond to external threats, pressures of the adult world, and financial commitments, and in doing so band together with likeminded, and trusted, individuals: many of whom share some degree of kinship. Drawing upon the descriptive terms allotted by Densley (2012, 2014), Mclean (2017) identified several developmental stages of gang evolvement: 'recreational', 'criminal', and 'enterprise' (see Fig. 1).

For McLean (2017), Young Street Gangs (YSGs) are recreational youth groups that engage in territorial violence. YSGs can be split into two sub-units: the 'outer layer' and the 'core'. The outer layer consists of local youth who affiliate with the core body but only minimally engage in offending. They are the least 'embedded' (Pyrooz et al. 2013), thus typically disengage from the group once they reach adulthood. The core body, by contrast, is the gang 'mainstay'. Although they constitute a minority, core members are the most embedded in the gang and become the most prolific offenders (see also VRU 2011). They view crime as intrinsic to their own identity, thus are deemed 'life-course persistent' offenders (e.g., Moffitt 1993; Farrington et al. 2006). McLean (2017) found that core individuals (working with other core members) were typically the most likely to contribute to gang organisation. The process entailed criminal identities transcending the individual to become part of overall group identity. In other words, the core body underwent refinement to

\footnotetext{
${ }^{3}$ Like Hallsworth and Young's (2006) heuristic typology of urban street 'collectives', designed for aiding law enforcement when selecting the most effective method of intervention when dealing with group offending, McLean's (2017) model likewise aims to contribute in a similar vein in the Scottish context.

${ }^{4}$ McLean notes that for individuals involved in drug-dealing SOCGs, prior involvement in YSGs in early adolescence is not a necessary pre-condition. However, a number of Scotland's most notorious gangsters acknowledged in (auto)biographical accounts early ties to YSGs in childhood where fearsome reputations, criminal connections, delinquent peers, and networks could be all be established or aided (See Boyle 1977; Ferris and Mckay 2001, 2010; Jeffery 2003; McKay 2006). Such accounts are likewise supported by a number of scholars and law enforcement (See Davies, 1998; Sillitoe 1956; VRU, 2011).
} 


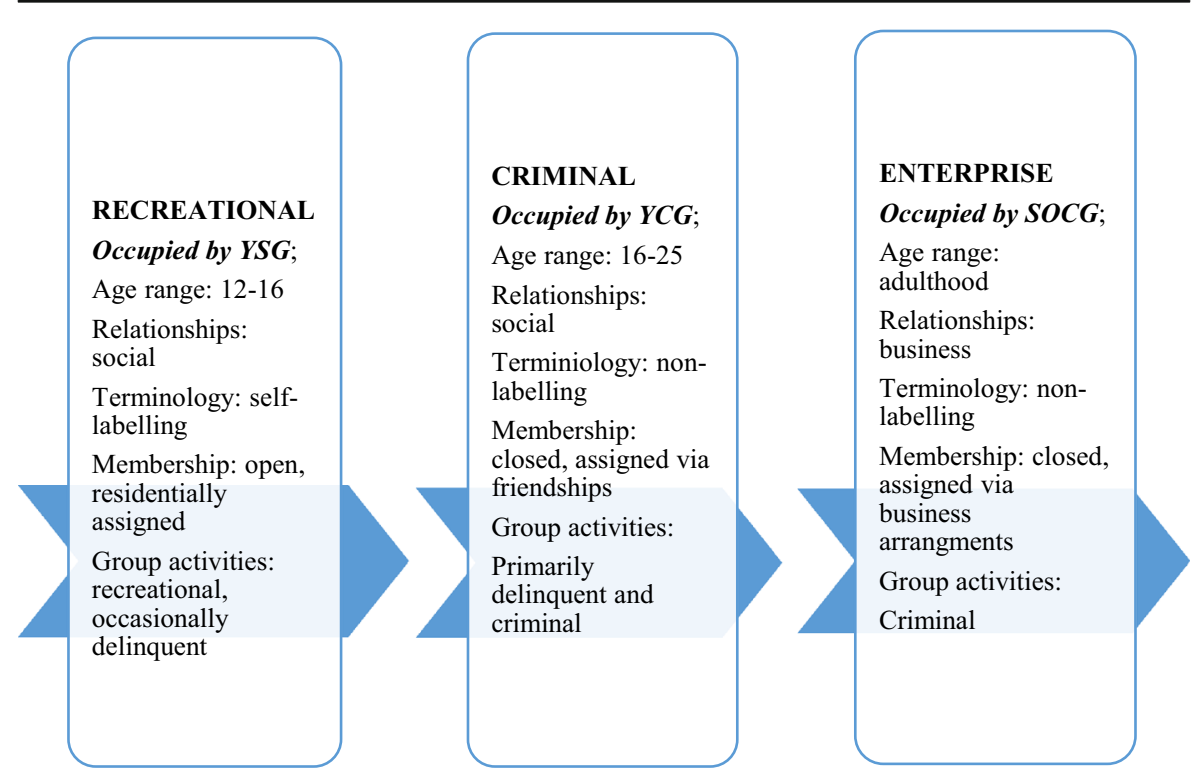

Fig. 1 McLean's (2017) evolving gang model

become a more coherent unit. Criminality became part of group intent, behaviour, and activity, at which point the YSG changes into a Young Crime Gang (YCG).

McLean (2017) argued that YCGs exist on an evolving continuum and differences remained even within gangs under the same stage of development. The term YCG, he argued, only applied to groups that managed to effectively move beyond retail-level drug supply to bulk buying and wholesaling practices. It is important to note that while YSGs tended to self-nominate themselves as a gang, for example 'Pollok Young Team' or 'Young Linty Goucho', YCGs no longer adhere to issues of territoriality, thus have ceased using related terminology.

McLean retained the Police Scotland term Serious Organised Crime Groups ${ }^{5}$ to describe those adult criminals operating at the upper echelons of the supply chain, but also elaborated upon the definition. For McLean, SOCGs were typically those adult groupings whose association with other members was primarily based on business and economic purposes, as opposed to social. While it was possible for a YCG to become a SOCG in its own right, this was rarely the case. Rather, particularly successful YCG members ceased associating with other group members deemed as 'risky' or a 'liability' and instead formed 'business alliances' with colleagues at the top of the supply chain. SOCG members operated in the gaps between the illegal and legal market, consequently ceasing to handle illegal commodities (like drugs) directly and instead handle money (see also, Murray 2016). The current study seeks to elaborate upon these findings, locating Glasgow's drug supply within the evolving gang model.

\footnotetext{
${ }^{5}$ Differences in gang and group terminology are not primarily based upon those activities being exerted but rather on the changing nature, and purpose, of the relationships involved (See Figure 3), along with general difference in age, given that gangs tend to be viewed a primarily youthful (see also, Klein and Maxson 2006).
} 


\section{Methods}

Data were collected between 2013 and 2016, as part of the first author's larger qualitative exploration of criminal networks in the Scottish context. Given that the Glasgow conurbation has continued to display a prevalent and historically embedded gang culture (Davies 2013; Deuchar 2013; Patrick 1973) and likewise retains a disproportional majority (70\%) of the country's OC, $65 \%$ of which is directly related to drug supply, the region was considered ideal for carrying out research (see Scottish Government 2015). Participant criteria were set as: (a) having had experience of group offending; (b) having been engaged in behaviour which Police Scotland identify as serious and organised crime (Scottish Government 2015); and (c) must be over 16 years of age. Participants were initially accessed via key outreach projects, whereby practitioners and outreach workers acted as gatekeepers. Gatekeepers were subsequently interviewed also. As a result of difficulties associated with accessing 'hard-to-reach populations', given participation in serious and organised (re)offending, 12 participants who met the set criteria were accessed (see Bhopal and Deuchar 2016). This approach in total yielded a sample size of 17 participants ( $n=5$ practitioners, $n=12$ offenders). However, having considered this sample size relatively small and possibly skewed, a snowball sampling technique was deployed thereafter whereby interviewees were asked to recommended potential participants also meeting the criteria. Becker (1963) suggests this is relevant where sampling frame is limited. This sampling technique yielded an additional 23 participants. In total, 40 participants were interviewed $(n=5$ practitioners, $n=35$ offenders).

In-depth interviews were carried out with participants. Of the 35 participants meeting the set criteria all bar one were male. All 35 considered themselves indigenous, although not all considered themselves Caucasian. In addition, all considered themselves to have been raised in Glasgow housing estates suffering particularly high levels of deprivation (see Scottish Government 2012). Likewise, most came from re-ordered family structures (see Roger 2008). Participants' ages ranged from 16 to 35. Interviews allowed the researcher to gain insights into the way participants understood particular events and situations. Open-ended interviewing allowed the interviewees to convey, unrestricted, their distinct subjective experience of their role within gang organisation as a means for gang business.

Effort was taken to keep interview questions open, enabling the researcher to respond to any emerging themes. The interview extracts selected in this article illustrate interviewees' personal construction of reality through their own voices. Whenever possible, multiple interviews were scheduled with participants. These ranged between one to five interviews each. On average, interviews lasted about one hour. Almost all interviews were conducted on a one-to-one basis, although two interviews were group interviews ( $n=4$ and 5). Whenever feasible, data were triangulated through discussions with other interviewees or by participants voluntarily providing corroborating evidence (i.e., media articles, criminal records, having others confirm statements made). Interviews were recorded via audio devices before being transcribed, coded, and analysed thematically (Creswell 1994). Ethical approval was granted by the researcher's home institution. Prior to interviews, an information sheet outlining relevant information was distributed. General research questions covered the following issues: has the participant been involved in offending? How did the participant become involved in organised crime? What role did the gang/group facilitate in this process, if any? What does drug supply look like in Scotland? 


\section{Findings}

The research findings are presented under three subheadings. Each subheading relates to drug supply processes within a specific gang 'type' as outlined by Mclean (2017). Therefore, the first subheading is 'YSGs and Drug Supply'. The second is 'YCGs and Drug Supply'. This is followed by 'SOCGs and Drug Supply'. Participant names are pseudonyms. In addition, some dates/locations have been altered to preserve confidentiality.

\section{YSG and drug supply}

Not all YSG members become involved in crime. In fact, most members simply take on membership status as a way of socialising with peers, under the pretence of expressing 'tough masculinities' whereby toughness, aggression, and bravado are held in high esteem as markers of social status (see Deuchar and Holligan 2010). As outlined in the review of Mclean's (2017) evolving gang model, the YSG can essentially be split into the core and the outer layer. Most youths who claim gang status belong to the outer layer (see also, Bradshaw 2005). For these youths, claiming gang status is merely how they express what Miller (2015) refers to as 'street socialisation': whereby scheme identity is projected as a common denominator amongst youths who share areas of social space, i.e. street corners, local shops, schools, parks, etc. (Whyte 1943). Former YSG member Harold, and Practitioners Clair and John explain:

'[I] use [to] hang about wi' a lot of boys in school. Like in a big group, you know mate. Was a good laugh.... Folk think you're up to no good cause you're in a group, but we were just hanging out, enjoying ourselves man.... Sometimes we would drink, usually at weekends though.... If we smoked weed it was more through the week.... Aye sometimes trouble kicked off, but that's always going to happen in big groups, aye, cause some people clash, don't they.' - Harold

'The crowds of boys we see on street corners aren't criminal. Don't get me wrong, they can be rowdy, but is that to say they are criminal, I think not. Young boys hung out in crowds when I was young, and still do today. They weren't gangs then, so why do we think they are now.' - Clair

'You got to understand, these [YSGs], they are mostly just [young boys] out pure having fun wi bravado and all... [sometimes though people get] stabbed.... or machete people during gang fights.' - John

The statements above suggest that YSGs, as a whole, are not inherently criminal, but rather recreational, even though at times they may retain delinquent features, such as being 'rowdy', 'drink[ing]', taking drugs, or, on occasion, fighting, which can result in people being 'stabbed'. Only the 'core' of the group adopt criminal identities. These few individuals will typically form a more cohesive unit around which the outer layer orbits, drifting to and fro. Continuing on from John's previous statement, he elaborates upon the core body: 
'You'll find it's usually only 3 or 4 individuals among [the YSG] who are like the right bad ones you [will] read about in the papers. That's the ones that go on to become like career criminals. [They] go on to do other serious stuff, no' always, but usually.' - John

Drawing upon years of experience in dealing with YSGs, John outlines that while most YSG members cease offending as they mature, those who belong to the core body typically continue to offend into adulthood and often become 'career criminals'. Part of the reason is that core members usually have stores of 'criminal capital' (Fader 2016) and ready access to sources of criminal socialisation (see Sutherland 1939). Youth workers Allan and Clair explain:

'On occasion, I come across young guys in here for dealing drugs, and I just know their life stories before they even open their mouths.... difficult upbringing, no reliable male role model, older brothers in and out of prison. Like the saying, the faces change but the stories don't.... You can tell from talking to them that they aren't going to change either.... It's a cycle.... usually they have been getting into bother since they were pups (pre-adolescent years).' - Allan

'Those who go on to become what we would deem, or.... label, career criminals, usually have shown criminal intent, or behaviour, throughout their lives at various points. They often come from unstable backgrounds .... I have found domestic abuse and erratic lifestyles to be very common, unfortunately... These kids grow up in this. Once adults (referring to mid-late adolescent years), [society] expects them to suddenly become mature, but I'm sorry that isn't going to happen. They have access to criminal networks, criminal friends and family.... what else do we truly expect when they and their friends become involved in criminal gangs.' - Clair

Allan and Clair also observe how core youth are over-exposed to certain 'risk factors' for offending and gang membership. Factors like, growing up in 'unstable' and at times 'erratic' households, having 'criminal friends and family', and having access to pre-existing 'criminal networks', which have been found to influence (but by no means determine) offending trajectories (Thornberry et al. 2003). Yet given that the YSG is a loosely connected peer group, with no solid hierarchy, or agreed group identity, such individuals are unable to project a criminal identity over the group as a whole. Rather, criminal offending from such individuals occurs periodically, opportunistically, and within pockets of the group (Mclean 2017). As pointed out by Allan, 'drug dealing' does occur within YSGs, but the way it occurs is far from being organised or even for significant financial gain.

Drug supply by YSGs members is very much akin to what Coomber and Moyle (2014) refer to as 'social supply,' where the line between user and supplier is often blurry. Drugs are generally procured and distributed by YSGs for social purposes. Mclean (2017) found that when YSGs members sold drugs regularly, more often it was core members who did so. This was because core members had pre-existing access to networks of drug supply and had built reputations as the 'go to guys' for drugs among YSG members and local youths. Clair explains drug supply within YSGs: 
'[Local youths] usually get their drugs from one or two of the [YSG core] members. We find these boys [in turn] get them from their family or the families of their best friends. You know, the ones they are always with. It is difficult to get them to stop this behaviour. I mean, easy money and [access to] cheap drugs. You give that to most 15 year olds, from anywhere, and they would snap it up. Even more so when it's normal behaviour in their own households ... drugs are normal to them.' - Clair

Clair states that because core members usually have a steady access to cheap drugs, they have a strategic advantage over other would-be dealers. However, YSG core members do not have the mental capability, experience, physical stature, or maturity to oversee a successful, and on-going, drugs operation (see Densley 2012; Hagedorn 1994). Rather, supply is sporadic, unplanned, and often carried out for the purpose of covering their own drugs habit, expenses, or to provide a little income. Former dealers Steg and Matt explain:

\begin{abstract}
'Most people start [by] selling a bit of weed. I started wi' Val[ium], just [be]cause I could get them easy from my bro[ther], who was into smack, shame, but he sold val's anyways. I got them and used to [distribute them] among the troops (YSG), just for a laugh really, giggles ... Suppose, it gave me a bit of a reputation. I liked that. Wasn't 'till I was older I thought about doing it for a living and selling the [heroin].' - Steg
\end{abstract}

'Most [the] time we (YSG) hung out, was spent getting high. [Would] meet up down the woods to take buckets ${ }^{6}$.... People would take turns getting the [cannabis]. I used to get it [from an elder sibling], but they (peers) had to pay me back.... or sometimes we would all chip in [financially to purchase drugs]. I got it but, so didn't pay.' - Matt

While drug supply does occur within YSGs, therefore, it primarily takes the form of social supply as opposed to drug-dealing proper (Coomber and Moyle 2014). This method typically originates via the YSG core body. If left unchecked, however, the core body may progress onto more serious forms of drug supply, and in the process, evolve into a more cohesive criminal gang that is more difficult to dismantle.

\title{
YCGs and drug supply
}

Research that explores the links between youth gangs and OC is well established in the Anglo-Welsh context (e.g., Densley 2012, 2013; Pitts 2008). The National Crime Agency (2013: 9) similarly recognise that 'areas high [in] gang activity.... tend to be areas where organised criminals are most active.' However, this has not been the case in Scotland. In Scotland, a substantial body of work exists on YSGs, ${ }^{7}$ but there remains little academic

\footnotetext{
${ }^{6}$ A method of consuming cannabis via a plastic bottle.

${ }^{7}$ McLean (2017) explores a number of reasons as to why there has been an overly fixative gaze placed upon the gang in the YSG stage of development, including 'assumed gang history', 'gang narratives', 'conventional wisdom of gang research, and 'labelling properties', amongst others.
} 
research exploring how groups of persistent offenders undertake criminal trajectories, progressing towards OC, and what role, if any, group offending plays in this. This section, therefore, not only seeks to establish YCG position in the drug supply chain, but also to briefly outline how YCG formation occurs. This is important because YCGs are essentially criminal gangs that do not self-identify in the traditional sense.

As discussed, YCGs are a remnant of the YSG core body. ${ }^{8}$ As YSG members age and mature, those belonging to the outer layer typically cease offending. Yet for core members, age and maturity bring greater criminal potential. With age comes physical development, mental maturity, entitlement to social housing and welfare, a driver's licence etc. Beyond seeing themselves as intrinsically criminal, YCG members also have greater criminal opportunities. Combined with prior criminal network ties, YCGs engage more successfully in drug supply. Billy explains:

'I had always been selling since I was a boy. Never really thought anything about it.... it was normal. [I] sold [cannabis] in High School.... My uncle [grew it].... I would get some from him.... was like my pocket money. [When 16 years old] I did some work [in a garage] ... wasn't for me like. I am a worker but can't take people telling me what to do.... selling [cannabis] was easier. Was a career choice.... I had a house at [17] so I could grow my own. Turned the spare bedroom into a [cannabis factory].' - Billy

As illustrated, age enabled Billy to capitalise on prior 'criminal learning' (e.g., Sutherland 1939) and engage more purposefully in drug supply. Now aged 17 and in possession of his 'own house', Billy was able to weigh up the pro's and con's in deciding whether or not drug-dealing proper would prove a beneficial 'career choice'. Yet such careers typically require a need for support: often in the form of peer involvement:

'It's [risky] selling drugs. When people know you're selling, you are always opening yourself up for [being robbed]. You do need backup in this game.... course you want to be low key, but you can't really mate, especially if business is booming. People aren't daft, they know you're selling and probably have a stash in the house.... [so] I phoned up my best mate, and said you want in on this? We had always [socialised], and he's [trustworthy].... so I knew he'd be well up for a wee earner (acquisitive crimes) .... [and] can well handle himself. Had a bit of a reputation.' - Billy

Billy indicates that in a market where recourse to law is unavailable, and clients cannot be trusted, there is a need to establish trustworthy partnerships (see also, Von Lampe 2016). His choice to sell drugs was largely individual, but the benefits of group work outweighed the risks of 'going solo' (Windle and Briggs 2015). Thus, Billy turned to those whom he trusted most. Knowing his friend had a 'reputation' as a 'hardman' (see Boyle 1977), Billy opted to sell drugs in a group context. He was not alone. Preferring to work in criminal groupings was common amongst participants, particularly where supplier/user distinctions overlapped, as Evens points out:

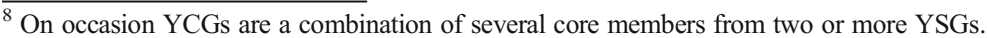


'Better working with mates. Can be pure hassle selling [individually]. More likely to get [robbed or assaulted], you know.... We [friends from the YSG core body] had always got on. Thick as mud (share a close relationships). ... can pure trust the boys, you getting me. [Working] together is easier.' - Evens

\section{I: Can you explain how it is easier to work in groups?}

'Aye it's like, if you pure fuck up a payment say.... cause sometimes you end up snorting half the gear on a weekend binge, getting the hookers round and having a coke party (laughs). ... [then] you still need to pay for what you've [been] given. ... if your mates have your back though man, then they can [assist financially]. ... you do the same for them. Everybody fucks up now and then.... selling and having an addiction can be a bad recipe.' - Evens

Evens found that working with trusted peers who were similarly criminally inclined had significant benefits, especially when drug suppliers were also drug users. However, the supplier-user overlap affected the ability of the group to evolve along the gang continuum. For example, YCG relationships centre on social aspects first, and economic aspects second, meaning that relapses in drug addiction prompted other group members to use their accumulated wealth to pay for their friends' habit and debts. Interestingly, interviewed SOCG members acknowledged that although at one time they too felt a moral obligation to their peers, once their group evolved, economic goals gradually took precedence over social ties. Thus, they were no longer obliged to 'bail out' other members when they messed up.

A key distinction between gang typologies lies in how gangs at each stage label themselves, or the manner in which they are referred to by others. YCGs do not selflabel like YSGs, whereby the prefix 'Young' typically precedes the 'scheme' or housing estate name (Miller 2015). Neither do YCGs label themselves, or are labelled by others, like SOCGs, whereby traditionally the SOCG is referred to by the notable member's family name, i.e. the 'Lyons Family', 'Thompson Family', or 'Kray twins' (McLean 2017). Rather, in an era where OC transcends first-generation kinship ties, YCGs do not adopt specific labelling properties, even if they self-identify as a criminal grouping. Practitioner John explains:

'The boys that deal [drugs] in groups don't label themselves by gang names. They don't call themselves like The Panthers or The Cobras. ... It's not like that.... I hear them refer to their [gangs], or other [YCGs] by.... the name of a guy they know in the gang.... Aye, [I can explain]. They might say something like [I] 'get [my drugs] off of Boab', or '[phone] Steg's team' [for drugs]. You know.... It's no' complicated, sound[s] it, but its no.' - John

Similarly, practitioner Clair adds:

'Tend to find they aren't a [YSG] as such. Well not in the way people perceive gangs [in Glasgow]. They are more a group of delinquents.... who [band] together through friendship. You put these guys together in groups with the same 
mentality then of course they are going to commit crime. They commit crime outwith the group so what's so different when they [band] together! If anything, it allows more criminal opportunity.... crime is a social activity.' - Clair

It would seem to 'get gear off Boab' or 'Steg's team' is the most commonly used method for group identification at the YCG stage. The term 'Boab' is plural not singular, despite only a single person's name being used. In another example, one YCG in the study consisted of members Peter, Robert, and Liam. When referring to the group, practitioner Clair named them 'Peter's group', while another interviewee called the YCG, 'Robert and his mates'. Windle (2013) similarly highlights the terminology used to refer to an Essex-based gang known as 'Tucker's' or 'Tucker's Firm,' whenever people were referring to the people who sold drugs with a man named Tucker. YCGs, therefore, may be referred to, or named, differently depending on the person doing the referring, and their proximity to the group. This was especially true when the groups under discussion comprised late adolescents involved in drug-dealing proper. Ryan discusses YCG labelling:

'Suppose, you could say we are a gang, but we wouldn't call ourselves Young Teams mate. That's for wee guys.... no cunt would take you serious.... [instead, we] are mates that also work together, [pauses]..... for dealing gear.' - Ryan

The lack of self-labelling can also be attributed to youths wanting to be taken 'serious' when transitioning from childhood delinquents to adult criminals. Similarly, as Ryan suggests, viewing co-workers as 'mates' as opposed to business associates may obscure emerging structures and group hierarchy. For such reasons, McLean (2017) primarily defines YCGs in terms of behavioural properties.

Trying to gauge those exact market level(s) within the illegal drugs trade that YCGs tend to operate is difficult, primarily because YCGs merge with or acquire other YCGs over time and the evolutionary process takes a considerable amount of time (e.g., Densley 2014). Where exactly a YCG operates is also largely subjective depending on who is being asked, their position in the market, knowledge of other suppliers, and of the market itself (see Pearson and Hobbs 2001). Generally speaking, however, the market is stratified according to whether or not the gang is orientated around 'retail-level distributors', 'wholesalers', or 'importers'. Former offender Yonah details the difficulties in gaging precise levels a YCG may operate in:

'Wouldn't say we (the YCG) were big. We were well known and brought in a couple of G[rand] from sales.... [for] drop offs [we carried out], [earnings] varied.... Moving [heroin] brought [good income]....[between] $£ 10,000-£ 20,000$ for each bulk shift[ed]. We didn’t sell it ourselves. Fuck that. Been there, done that. Would give (sell) to people to do that.... [if] we earned $£ 10,000$, it's no[t] as though you get that for yourself. [It] get[s] [divided] up [with group members].... Am sure there are boys out there earning much more, but anyone we worked with never earned like the kind of money the papers tout, $£ 1,000,000$ here and there.... bollocks. You never know suppose, [because] people always talk shit about what they [earn]. If 
they have a good earner.... they keep it quiet so cunts don't muscle in. But see if they [claim] they bring in [particularly large sums] then they are probably talking pish.... wanting a rep.' - Yonah

Yonah points out that YCGs rarely brought in any more than five figure sums. He attributes much of the myth surrounding drug supply and high earnings to media dramatization, or people 'talking pish' to earn a 'rep'. In addition, Coomber and Moyle (2014) found that methods of measuring supply value may differ considerably between suppliers/users and the political establishment. Yet, Yonah acknowledges that even if other groups, akin to his own, did earn considerably more, they often took steps to keep this concealed. Secrecy significantly hinders efforts to precisely locate gangs at specific market levels. Yet a common trait mentioned by participants, like Yonah, involved in YCG drug supply is 'bulk buying' and 'bulk selling'. Police Scotland similarly ascribe drugs traded in metric measures as a way of determining those involved in the higher echelons of the supply chain (Pearson and Hobbs 2001). Yet while Yonah's YCG had no intentions to operate at retail-level dealerships, this was not a unanimous consensus amongst all those involved in YCGs. Donald explains:

'Take what you can get. If the opportunity is there to get cash coming in.... do it. I don't like [selling drugs individually]. Can be dodgy.... [customers] always up at your door, day and night.... Police can come crashing through [anytime] .... [When working in the group context, we] always stash elsewhere at a [female associates] house.... but when things (drug supply) dry up, it's no[t] like she has anything to keep. She isn't going to take risks for fuck all .... [so that is when] I keep the gear in my own house and [sell drugs individually at retail-level]. Still need money coming into the house.' - Donald

While bulk-buying in YCG formation is preferable, for Donald, retail-level distribution is not beyond him when required. Donald indicates that supply behaviour is largely driven by opportunity and market ebb and flow. Yet, for Yonah, having 'been there, done that', he is no longer interested in the risk involved in retail-level distribution. Given that YCG formation occurs over time, it is likely Yonah's YCG is much more developed, and had greater longevity, than Donald's YCG. The ability to consistently undertake wholesaling practices takes time to develop.

\section{SOCGs and drug supply}

McLean (2017) points out that one of the main differences between YCGs and SOCGs is that of relationship/membership purpose. YCGs may engage in crime, but crime is largely an outcome of social relationships between intrinsically criminal individuals who are young and now faced with external threats and financial pressures. SOCGs, on the other hand, are adults who have matured physically, socially, and emotionally, and now base new and existing relationships upon maximum utility and profitability. Social aspects are still important, only second to economic considerations. Hence, YCGs will put up with other members' erratic or 'bad' behaviour, while SOCGs will not. Bad behaviour is bad for business. Very often SOCG members will distance themselves, or keep at arm's length, 
individuals who place self-interest above group interest or masculinity and territoriality before profitability and growth. Former SOCG member Harold explains:

'No one really knew what I was getting up to, until I got busted of course (laughs). I basically kept myself to myself and kept my distance from [former YCG associates]. They were too wild man and were always going to end up dead. I missed hanging out wi' them, still do man, but they were bad news. Just never grew up.... I [eventually forged an alliance] with a guy had done some business with in the past. He done alright for himself and just said if I wanted to help him out... only if I ditched my mates but.' - Harold

Harold says that while, at one time, he was involved in drug supply with childhood friends in YCG formation, he was approached as an adult by another individual, who had also previously been a YCG member in another outfit, but was now successfully involved in high level OC. Harold and this individual forged a new relationship based upon business; evident by the fact Harold was asked to 'ditch' his old friends because they may have brought unwanted attention. Both Harold's friends from the YCG would eventually be killed violently in unrelated incidents which centred on issues of masculinity and territoriality. As Evens remarked earlier, YCG relationships may hinder the group's overall ability to organise as a means for gang business and evolve into a SOCG. Many YCGs fail to move beyond this stage of development owing to a lack of strategic thinking. Being 'strategic' allows SOCGs to reach the higher echelons of OC, said respondents. In relation to drug supply, being strategic not only meant bulk buying, or buying better product, but also importing directly. Former offender Sean, who had spent a considerable duration in prison for drug supply, explains:

'I only worked alongside one guy. No more than that. He arranged transport[ation] of goods into the country. I picked up at the other end. He had his connections over there (in exporting country), I had mines here (in importing country)' - Sean

Having been imprisoned for importing drugs into Britain, Sean understood that at the higher echelons of OC, group dynamics were akin to a tight-knit business partnership rather than a loose-knit friendship. Business partners may well spend some time socialising, but the goal is to promote cooperation in business, much like how executives entertain their clients at corporate hospitality events. Should either party fail to uphold their 'unofficial contractual obligations' once terms are agreed, then relations cease. If a better offer comes along, moreover, then business partners are easily replaced. It is nothing personal, just business, Sean explains:

'We weren't pals. I knew him through someone who introduced us. I liked the guy, but see if someone else came along wi' a better deal, then I would have forgot him in [an instance]. He'd have fucking done the same to me as well. There isn't no loyalty. Money doesn't have loyalty.' - Sean

Sean's statements would suggest that the common image of the 'gang' (e.g., Klein and Maxson 2006) is not typical of the groups operating at the higher levels of OC. For example, SOCGs were clearly hierarchically organised: 
'They (other SOCG members) aren't like [friends]. We did business together.... Functions better that way mate. [With friends], [people] are always trying to outdo each other.... This wasn't a problem for us. You need to know your place.' - Derek

Not content with being providers of illegal drugs, SOCGs also sought to become the only providers of illegal drugs within their respective domains (Varese 2010). Referencing Mexican drug cartels, Calderon (2015) notes that those involved in the higher echelons of drug supply tend to try and move beyond 'drug trafficking' toward monopoly control of markets, territory, and the activities of others. Scotland's SOCGs appear no different. Practitioner David explains:

'[Those involved] in high end drug distribution basically control the market. A few guys.... run it all. That is why you always hear of one or two names [criminals] running the show. Everyone works for them, no always directly mind you. Most people don't even probably know they get their gear off them.... The guys running it basically can [be]cause they get a wee foothold, bring their family and closest mates in and start using violence to keep anyone who tries to muscle in, out of the picture.... saying that but, violence only gets you so far. Loads of crazy [people] out there but who don't care.... Being involved in [OC] but means they can turn to corrupt cops, MPs, and what have you. If you cannot batter the competition out, then rule them out [with law].' - David

David's statement clarifies that although many groups are involved in retailing drugs, purchasing them in bulk, and, to a lesser extent, importing them, only those who are involved in true 'wholesaling' practices can be considered OC. Wholesaling is made possible through innovation and strengthening relationships. In short, SOCGs are YCGs with increased market share. Higher market share puts SOCGs at a competitive advantage. SOCGs receive better prices from importers (or indeed, they are the importers) and larger order volumes increase their buying power. It is buying power that enables SOCGs to control markets from above (not below) using economies of scale. They purchase much larger quantities than the average dealer, for a unit price that is lower, thus they dictate retail prices further down the supply chain. In other words, SOCGs are the hedge funds and day traders of the illicit drugs market. Their members are 'business men', and very often they do enter the legitimate marketplace as well, even if only to launder profits.

\section{Discussion}

The purpose of the article was to help shed light onto existing gang typologies and how they fit within Scotland's illegal drugs market. ${ }^{9}$ In doing so, the current study has drawn upon McLean's (2017) evolving gang model, and examined how these gang/group

\footnotetext{
${ }^{9}$ Individual dealers do also operate in the drugs market, but primarily at the retail level. Further, while people at the apex of the supply chain very much operate for individual gain, not group gain, they are not 'solo' in the strictest sense, but rather operate in loose partnerships and groups.
} 
typologies participate in drug supply. Findings suggest drug supply and gang typology are very much intertwined. A similar trend has been observed in prior research, whereby gangs/groups have become increasingly involved in drug supply in what is now essentially a globalised era (e.g., Pitts 2008). Yet there is also considerable variation in the ways different types of gangs participate in drug supply. Specifically, YSGs are recreational youth gangs with almost no role in drug supply. When drug selling occurs, often it happens via core members accessing pre-existing networks to undertake social supply, not drug-dealing proper. Next, YCGs are involved in, or seek to be involved in, bulk-buying practices. Therefore, to help avoid over-criminalisation of YSGs, only groups who engage in consistent bulk-buying can be classified as YCGs. Membership of YCGs typically comprises former YSG core members who pull together experience, resources, and criminal knowhow to progress up the supply chain. Finally, SOCGs are involved in both importing and wholesaling practices. SOCGs are not a gang per se, but rather loose partnerships based upon mutually beneficial business arrangements. Generally, SOCGs do not handle drugs directly and will likewise be involved in actions which straddle the legitimate and illegitimate spheres. The research does not dispute current terminology used by Police Scotland, therefore, but rather looks to refine it.

To help place these findings into context for easy interpretation by practitioners and law enforcement, the findings are now placed within Pearson and Hobbs' (2001) model of the UK's illegal drugs market. Pearson and Hobbs' model is uniquely applied here to the Scottish context. As Aldridge (2011) notes, regional differences within the UK may not only see gang types differ but also activities they are involved in. Likewise, note that market level is defined in terms of how gangs purchase, store and supply drugs, as opposed to making reference to a specific drug type. Figure 2 (below) illustrates the position of the illegal drugs market that Scottish gangs are likely to operate within and likewise makes reference to whether or not such activities can truly be considered OC. Where activities cannot be considered OC (due to the lack of efforts to actually control the

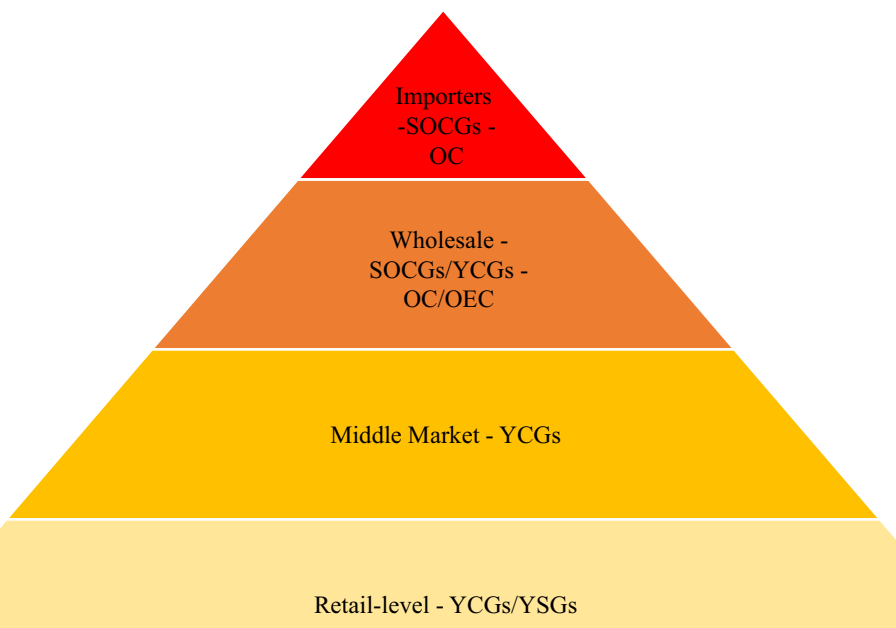

Fig. 2 McLean's evolving gang model within Pearson and Hobbs' UK illegal drugs market 
market), the term 'Organised Effort of Crime' is applied (see McLean 2017). This indicates that efforts are being made to engage in OC, but as of yet this is limited:

Figure 2 shows that although some YSG members may be involved in retail-level drug supply, this is very much the exception not the rule. Only as the core of the YSG begins to mature are they able to move beyond social supply to form YCGs that can penetrate higher levels of the illegal drugs market. The old core members may act as 'middle men' distributors and even begin to partake in bulk-buying practices, refined over time by bringing in close friends and family (who have come through this process of gang evolution with them). The YCGs that thrive (i.e., avoid law enforcement action) or merge to consolidate operations and increase market share, eventually graduate on to wholesale buying, which if sustained can be indicative of SOCG potential. These groups are not yet OC for they do not seek to monopolise the market, but they are OEC. With increased market share, however, the possibility of SOCG can be realised. The group begins to import and wholesale drugs and manipulate the market in a given region, or, in extreme cases, the entire country. Only by adopting businesslike principles can gangs continue to refine and effectively become SOCGs. Figure 3 (below) illustrates this point by drawing upon a YCG and a SOCG which may both have three members:

The above illustrations show that power distribution (illustrated by circle size) and the blur between business and social dimensions of group member relationships (shown here via circle overlap) means that the business conduct necessary for engagement in $\mathrm{OC}$ is unattainable while gangs remain in the YCG formation. Once members establish a hierarchy and disentangle their social and economic goals, can they move beyond drug supply and towards market control. Yet having now made the distinction between gang type and supply type, and even incorporating whether or not some activities are truly OC or more akin to OEC, we are left with the question of how to put such insights into good policy and practice.
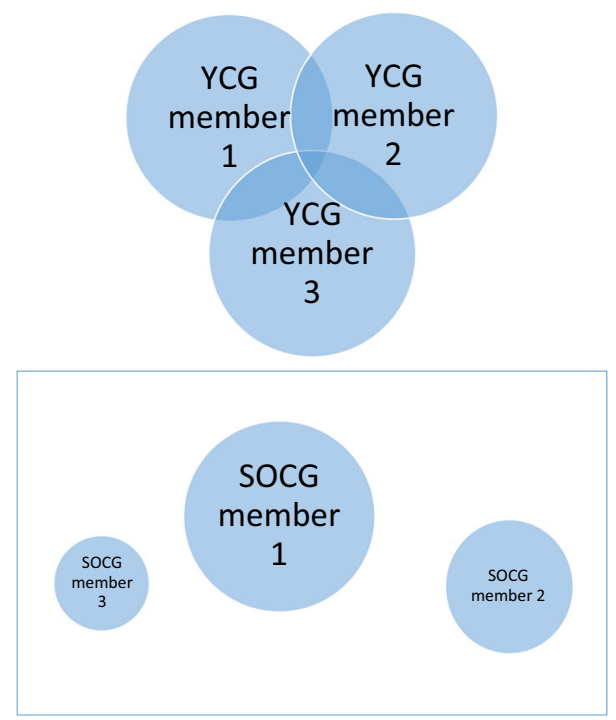

Fig. 3 YCG relationships (top), SOCG relationships (bottom) 
To summarize, YSGs constitute 'gangs' owing to their involvement in delinquency and the tendency of their members to self-identify as gang members. Likewise, YCGs can also be classified as gangs due to the efforts they make to organise for crime and move beyond individual retail-level drug dealing. Strength in an uncertain and highly dangerous world can be found in numbers, thus while YCG members recognise they are part of a criminal gang, they do not adopt the "conventional and other symbolic signals" (Gambetta 2009: xix) of membership expected of gangs in the Scottish context. SOCGs though are not a gang per se. They are primarily individual criminals who recognised the importance and necessity for criminal partnerships and working with others, yet often through experience also realise over time that social aspects and direct handling of drugs is disadvantageous and thus must be avoided to be, and remain, successful. An important distinction between YCGs and SOCGs, in regards to group structure, is that relationships are based primarily on business principles, and in regards to drug supply, SOCGs make efforts to control the market they operate within, while YCGs simply look to move drugs from A to B. In addition, it would also seem that YCGs may provide alternative benefits beyond being the linchpin between professional activity and retail-level distribution. YCGs can arguably serve as a criminal conveyer belt, whereby successful individuals in well-established SOCGs may select, or offer criminal opportunities, to those more astute YCG members who have proven themselves worthy and competent, time and again.

\section{Conclusion}

The findings presented herein can go some way to helping the SNP achieve their objective of a 'drug free' Scotland, or at least more realistically conceptualize drug supply in an effort to address it (note, drug demand is another issue). This article situates Scottish gang typology within the illegal drugs market model, and in doing so makes it possible to distinguish not only between gang type but also supply type. Drug supply amongst youths is primarily social supply and as such this finding works in conjunction with Scotland's 'welfarist' paradigm concerning juvenile criminal justice. Yet such insights do identify those individuals whom are most likely to progress onto more serious and organised types of acquisitive crime. This may facilitate development of early intervention policies, drawing upon those risk and protective factors also described by Farrington et al. (2006), Thornberry et al. (2003) and others. This could prove pivotal in ceasing criminal trajectories in their path. Yet for those individuals who do go on to form YCGs, it is equally important to distinguish them from youth who comprise SOCGs.

While much of the gang's structure and behaviour would fit the SOCG criteria, gang relationships and the lack of effort to control and regulate illegal markets would suggest otherwise. This is important given that criminalising offenders has been found to only increase gang cohesion (Klein 1995). Likewise, making this distinction also halts the improper use of the Proceeds of Crime Act 2002 whereby commodities and income can be confiscated if not proven to have been legitimately earned (Sproat 2011, 2012). It is very likely that should the YCG be broken up then individual perceptions of being intrinsically criminal would not be able to transcend onto group practices as a whole. While it is arguable that such individuals would still offend, at least breaking up YCG 
formation would potentially limit the level, and seriousness, of these offences. Halting the group's ability to combine resources would mean they would not be able to engage successfully and consistently in wholesaling practices.

Rather than criminalising offenders on the periphery of $\mathrm{OC}$ as being members of a SOCG or a crime syndicate, moreover, every effort should be made to rehabilitate such individuals back into society. All of those interviewed who had been involved in SOCG that supplied drugs had had prior periods of imprisonment. Thus, while it was an unexplored issue it would appear that imprisonment had little effect on deterring future criminal practices (See Scottish Government 2013). Arguably, the term OC is one which should be reserved to SOCGs alone who operate at the apex of the illegal drugs market (i.e. importing and wholesaling). This is because they are involved not only in large scale drug trafficking, but also involved in controlling the drugs market through fear, intimidation, and violence (Calderon 2015). This can often overspill onto violence on the streets (See Ferris and Mckay 2001; Windle 2013).

The Scottish Police Authority (SPA, 2013: 1) estimates OC costs the Scottish economy approximately $£ 2$ billion per annum, and has highlighted the need to identify specific 'roles and responsibilities performed by selected individuals' so that tactics can be tailored to deliver the most 'appropriate and proportionate policing response'. Further, in its 'Policing 2026' 10-year strategy, Police Scotland (2016) recognises that the work of SOCGs has become increasingly sophisticated and that the service increasingly faces 'significant demand in respect of investigations into ... Serious Organised Crime'. Scotland's Serious and Organised Crime Taskforce is a multi-partner strategic forum established by the Scottish Government and is focused on four distinct elements: diverting individuals (particularly young people) from engaging in $\mathrm{OC}$; deterring SOCGs; disrupting their activities; and detecting their members by boosting policing capacity and improving coordination to give them 'no place to hide' (SPA, 2013: 3).

The data emerging from our empirical research with offenders involved in OC and practitioners who work with them provide somewhat unique, ground-breaking insights into the precise levels of gang involvement in the one particular aspect of OC: namely, drug supply. In particular, the insights that suggest that members of YCGs are regularly involved in wholesale work and in OEC, but also on occasions adopt business principles in order to become SOCGs, or be absorbed into existing SOCGs, enable an increased level of sharpness to Police Scotland's investigations. Our insights have the capacity to support Detectives with their ongoing vision to dismantle drug supply networks by providing them with a new evidence-base that suggests the need to target linchpin areas such as YCGs, while simultaneously avoiding a situation where minor offenders (who may be members of YSGs or "reluctant gangsters" (Pitts 2008)) are brought into the fold and criminalised. Accordingly, in being more acutely aware of gang type and supply type, Police Scotland will be able to target high-end offenders, as opposed to what Ratcliffe (2008) called 'low-hanging fruit'. This will ultimately enable the SNP to more effectively craft a 'drug free' Scotland from the supply side (as opposed to demand-side).

Still, exactly where different gang types are involved or situated in the illegal drugs market needs further clarification. For example, market levels in the study still have to be defined by product. The research here suggests that while YSG primarily sell cannabis, YCGs and SOCGs deal in a variety of substances that vary considerably and also from gang to gang. If YCG A bulk buys heroin, for example, this does not automatically mean that they purchase, store, or sell cannabis in the same manner. The way the gang interacts 
with each drug type may also differ. Some YCGs and SOCGs were found to grow cannabis in homemade factories, while they simultaneously stock-piled cocaine in 'warehouses'. ${ }^{10}$ Other gangs were more specialized in the product they dealt in.

Ultimately, while this research lays a firm foundation from which the political establishment, law enforcement, interventionist organisations or academics can work from, further research is required to detailed the markets and drug types within. Another point which requires further attention though is that of criminal associates. For example, while YCGs and SOCGS store drugs and other illegal goods, they often do so with the help of unwilling participants (i.e., drug users looking to pay off drug debts) or friends (partners) and family members compelled to assist. While not part of the criminal gang, they are complicit in criminal behaviour. One question for future research is whether they are perpetrators or victims or both. The SSOCS (Scottish Government 2015) fails to distinguish between the two, and thus potentially criminalises victims of crime. In addition, a final point for clarification is that of payment. Many of the SOCGs were found to change the currency of payment from money to (primarily) drugs, along with other illegal goods, weapons, or property. This needs further investigation if drug supply is ever to be halted and criminalising tendencies avoided.

\section{Compliance with ethical standards}

Conflict of interest The authors declare that they have no conflict of interest.

Ethical approval All procedures performed in studies involving human participants were in accordance with the ethical standards of the institutional and/or national research committee and with the 1964 Helsinki declaration and its later amendments or comparable ethical standards.

Informed consent Informed consent was obtained from all individual participants included in the study.

Open Access This article is distributed under the terms of the Creative Commons Attribution 4.0 International License (http://creativecommons.org/licenses/by/4.0/), which permits unrestricted use, distribution, and reproduction in any medium, provided you give appropriate credit to the original author(s) and the source, provide a link to the Creative Commons license, and indicate if changes were made.

\section{References}

Aldridge J (2011) Review of Reluctant Gangsters: The Changing Face of Youth Crime by J Pitts. Youth Justice 10:202-204

Bartie A (2010). "The new wave of Glasgow Hooliganism": Moral panics and Glasgow gangs, 1965-70. Contemp Br Hist 24:385-408

Becker H (1963) Outsiders. Free Press, New York

Bhopal K, Deuchar R (2016) Researching marginalized groups. Routledge, New York

Bjerregaard B (2010) Gang membership and drug involvement: untangling the complex relationship. Crime Delinq 56:3-34

Bouchard M, Spindler A (2010) Gangs, groups, and delinquency: does organization matter? J Crim Just 38:921-933 Boyle J (1977) A sense of freedom. Pan Books, London

\footnotetext{
${ }^{10}$ These warehouses included residential spaces, the households of loved ones, garages, garden sheds, shops, and large underground storage containers (often self-constructed).
} 
Bradshaw P (2005) Terrors and young teams: youth gangs and delinquency in Edinburgh. In: Decker SH, Weerman FM (eds) European street gangs and troublesome youth groups. AltaMira Press, Oxford

Calderon F (2015). Drug trafficking and organized crime: connected but different. Harv Int Rev 36: http://hir. harvard.edu/article/?a=11786

Casey J, Hay G, Godfrey C, Parrot S (2009) Assessing the scale and impact of illicit drug Markets in Scotland. Scottish Government, Edinburgh

Cloward R, Ohlin L (1960) Delinquency and opportunity. Free Press, New York

Cohen A, Short JF Jr (1958) Research in delinquent subcultures. J Soc Issues 14:20-37

Coomber R (2004) Drug use and drug market intersections. Addict Res Theory 12:1-5

Coomber R, Moyle L (2014) Beyond drug dealing: developing and extending the concept of 'social supply' of illicit drugs to 'minimally commercial supply'. Drugs Educ Prev Pol 21:157-164

Coomber R, Moyle L (2017) The changing shape of street-level heroin and crack supply in England: Commuting, holidaying and cuckooing drug dealers across 'County lines'. Br J Criminol https://doi. org/10.1093/bjc/azx068

Coope S, Bland N (2004) Reducing the impact of local drug markets: a research review. Scottish Executive, Edinburgh Creswell J (1994) Research design: qualitative, quantitative, and mixed methods approaches. Sage, Thousand Oaks Curry GD (2000) Self-reported gang involvement and officially recorded delinquency. Criminology 38:1253-1274

Davies, A. (1998) Street gangs, crime and policing in Glasgow during the 1930s: The case of the Beehive Boys. Soc Hist 23(3):3-4

Davies A (2007) The Scottish Chicago? From hooligans to Glasgow in the late 1920's. Cult Soc Hist 4:511-527

Davies A (2008) Street gangs, crime and policing in Glasgow during the 1930's: the case of the beehive boys. Soc Hist 23:251-267

Davies A (2013) City of gangs: Glasgow and the rise of the British gangster. Hodder \& Stoughton, London

Decker SH (2000) Legitimating drug use: a note on the impact of gang membership and drug sales on the use of illicit drugs. Justice Q 17:393-410

Decker SH, Pyrooz DC (2013) Gangs: another form of organized crime? In: Paoli L (ed) Oxford handbook of organized crime. Oxford University Press, New York

Decker SH, Bynum T, Weisel D (1998) A tale of two cities: gangs as organized crime groups. Justice Q 15:395-425

Decker SH, Katz C, Webb V (2008) Understanding the black box of gang organization: implications for involvement in violent crime, drug sales, and violent victimization. Crime Delinq 54:153-172

Densley J (2012) The organisation of London's street gangs. Glob Crime 13:42-64

Densley J (2013) How Gangs Work. Palgrave MacMillan, New York

Densley J (2014) It's gang life, but not as we know it: the evolution of gang business. Crime Delinq 60:517-546

Deuchar R (2009) Gangs, marginalised youth and social capital. Trentham, Stoke on Trent

Deuchar R (2013) Policing youth violence: transatlantic connections. Institute of Education Press, London

Deuchar R, Bhopal K (2017) Young people and social control: problems and prospects from the margins. Palgrave MacMillan, Basingstoke

Deuchar R, Holligan C (2010) Gangs sectarianism and social capital: a qualitative study of young people in Scotland. Sociology 44:13-30

Fader JJ (2016) Criminal family networks: criminal capital and cost avoidance among urban drug sellers. Deviant Behav 37(11):1325-1340

Fagan J (1989) The social organization of drug use and drug dealing among urban gangs. Criminology 27:633-667

Farrington D, Coid J, Harnett L, Jolliffe D, Soteriou N, Turner R, West D (2006) Criminal careers and life success. Home Office, London, London

Ferris P, Mckay R (2001) The Ferris conspiracy. Mainstream, Edinburgh

Ferris P, McKay R (2010) Villains: It takes one to know one. Black and White Publishing, Edinburgh

Fleisher M (2015) Gangs and drugs. In: Decker SH, Pyrooz DC (eds) The handbook of gangs. Wiley, Hoboken

Fraser A (2015) Urban legends: gang identity in the Post-industrial City. Oxford University Press, Oxford

Gambetta D (2009) Codes of the underworld. Princeton University Press, Princeton

Hagedorn J (1994) Neighbourhoods, markets and gang drug organization. J Res Crime Delinq 31:264-294

Hales G, Hobbs D (2010) Drug markets in the community: a London borough case study. Trends Organised Crime 13:13-30

Hallsworth S, Young T (2006) Urban collectives: gangs and other groups. Report for Operation Cruise. Metropolitan Police Service, London

Hallsworth S, Young T (2008) Gang talk \& gang talkers: a critique. Crime Media Cult 4:175-195

Hughes L A (2005). Studying youth gangs: Alternative methods and conclusions. J Contemp Crim Justice 21: 98-119

Jeffery R (2003) Glasgow's godfather: the astonishing inside story of Walter Norval, the City's first crime boss. Black and White Publishing, Edinburgh 
Klein MW (1995) The American street gang. Oxford University Press, New York

Klein MW, Maxson CL (2006) Street gang patterns and policies. Oxford University Press, New York

May T, Hough M (2004) Drug markets and distribution systems. Addict Res Theory 12:549-563

McCallum F (2011) SPICe briefing: knife crime. Scottish Government, Edinburgh

McCarron M (2014) It is in the interests of justice and health to decriminalise drug users. Scott Justice Matters 2:17-18

McKay R (2006) The Last Godfather: The life and crimes of Arthur Thompson. Black and White Publishing Limited Edinburgh

McLean R (2017) An evolving gang model in contemporary Scotland. J Deviant Behav. https://doi. org/10.1080/01639625.2016.1272969

McPhee I (2013) The intentionally unseen: Illicit \& Illegal Drug use in Scotland. Lambert Academic Publishing, Saarbrucken

McPhee I, Duffy T, Martin CR (2009) The perspectives of drug users within the social context of drug prohibition. Drugs Alcohol Today 9:2

Miller J (2015) In every scheme there is a team: a grounded theory of how young people grow in and out of gangs in Glasgow. Unpublished M.Ed Thesis, University West of Scotland

Moffitt TE (1993) Adolescence-limited and life-course-persistent antisocial behavior: a developmental taxonomy. Psychol Rev 100:674-701

Murray K (2016) The value of understanding organised crime business structures and processes: background paper commissioned by the EMCDDA for the 2016 EU drug markets report. European Monitoring Centre for Drugs and Drug Addictions

National Crime Agency (2013) Serious and organised crime strategy. Home Office/HM Government, London

Patrick J (1973) A Glasgow gang observed. Methuen, London

Pearson G, Hobbs D (2001) Middle market drug distribution: Home Office research study no. 227. Home Office, London

Pitts J (2008) Reluctant Gangsters. Willan, Devon

Preble E, Casey JJ (1969) Taking care of business: the heroin user's life on the streets. Int J Addict 4:1-24

Pyrooz DC, Fox A, Katz C, Decker SH (2011) Gang organization, offending, and victimization: a crossnational analysis. In: Esbensen F-A, Maxson C (eds) Youth gangs in international perspective: Tales from the Eurogang program of research. Springer, New York

Pyrooz DC, Sweeten G, Piquero A (2013) Continuity and change in gang membership and gang embeddedness. J Res Crime Delinq 50:239-271

Ratcliffe JH (2008) Intelligence-led policing. Willian, Devon

Roger JJ (2008) Criminalising social policy: anti-social behaviour and welfare in a Decivilized society. Willian, Devon

Scotland P (2016) Policing 2026: our ten-year strategy for policing Scotland. Police Scotland, Dalmarnock

Scottish government (2008) The road to recovery: a new approach to tackling Scotland's drug problem. Author, Edinburgh

Scottish Government (2009a) Assessing the scale and impact of illicit drug Markets in Scotland. Author, Edinburgh

Scottish Government (2009b) Road to recovery: tackling Scotland's drugs problem one year on. Author, Edinburgh

Scottish Government (2012) Scottish index of multiple deprivation. Author, Edinburgh

Scottish Government (2013) Reconviction rates in Scotland: 2012-13 offender cohort. Author, Edinburgh

Scottish Government (2015) Scotland serious organised crime strategy report. Scottish Government, Edinburgh

Scottish Police Authority (2013) SPA Board Meeting Agenda: Serious Organised Crime. Kilmarnock: SPA, $4^{\text {th }}$ December. Available at: http://www.spa.police.uk/assets/126884/199545/item5 Accessed on 12th July 2017

Sheley J, Zhang J, Brody C, Wright J (1995) Gang organization, gang criminal activity, and individual gang members' criminal behavior. Soc Sci Q 76:53-68

Short J (1998) The level of explanation problem revisited: the American Society of Criminology 1997 presidential address. Criminology 36:3-36

Sillitoe P (1956) Cloak without dagger. Cassell, London

Spergel I (1995) The youth gang problem: a community approach. Oxford University Press, New York

Sproat PA (2011) The serious and organised crime agency and the National Crime Squad: a comparison of their output from open source materials. Polic Soc 21:343-351

Sproat PA (2012) Phoney war or appeasement? The policing of organised crime in the UK. Trends Organised Crime 15:313-330

Stevens A (2008) Weighing up crime: the over estimation of drug-related crime. Contemp Drug Probl 35:265-290

Stimson G (2000) Blair declares war: The unhealthy state of British drug policy. Int J Drug Policy 11: 259-64

Storrod M, Densley J (2017) 'Going viral' and 'Going country': The expressive and instrumental activities of street gangs on social media. J Youth Stud 20:677-696

Sutherland EH (1939) The professional thief. University of Chicago Press, Chicago 
Taylor C (1990) Dangerous society. Michigan State University Press, East Lansing

Thornberry TP, Krohn M, Lizotte A, Smith C, Tobin K (2003) Gangs and delinquency in developmental perspective. Cambridge University Press, New York

Thrasher F (1927) The gang. University of Chicago Press, Chicago

Varese F (2010) General introduction: what is organized crime? In: Varese F (ed) Organized crime, critical concepts in criminology. Routledge, London, pp 1-33

Violence Reduction Unit (2011) The violence must stop: Glasgow's community initiative to reduce violence. Second Year Report. VRU, Glasgow

Von Lampe K (2016) Organized crime. Sage, Thousand Oaks

Whyte WF (1943) Street corner society. University of Chicago Press, Chicago

Windle J (2013) Tuckers frim: a case study of British organised crime. Trends Organised Crime 16:382-396

Windle J, Briggs D (2015) Going solo: the social organisation of drug dealing within a London street gang. J Youth Stud 18:1170-1185

Yablonsky L (1962) The violent gang. Macmillan, New York 